\title{
Reform of College Computer Basic Course for Talent Training Mode Innovation
}

\author{
Xin Sui, Rujuan Wang, Gang Hou, Lina Liu \\ College of Humanities \& Sciences of Northeast Normal University, Chang Chun, 130117, China
}

\author{
Keywords: College Computer Basic Course; Teaching Concept; Teaching Methods; Teaching \\ Reform; Talent Training Mode
}

\begin{abstract}
The college computer basic course is compulsory course for students of all majors. With the rapid development of information technology, in order to adapt to the demand for talents from the perspectives of social, economic and technological development, it is quite significant to further enhance the instruction and cultivation of undergraduates. This paper mainly aims at the problems existing in the college computer course, and reform from the teaching concept, teaching methods and other aspects which is based on the computational thinking. Through the practice of teaching reform, the students' learning interests are greatly improved, and the teaching effect is improved which is helpful to the new talent training mode.
\end{abstract}

\section{Introduction}

With the rapid development of information technology, computers and networks have penetrated into all areas of society, mastering the computer application technology and making full use of information resources are the basic requirements for the cultivation of talents in the new century. [1]" The college computer course" is a compulsory course for the students of the University, which has been set up by the Ministry of education.

The explosive emergence of knowledge, the increasing social demands on computer ability of college graduates, college students have to force how in the limited time to seriously consider, make full use of the advantages of teaching resources to selective learning. [2]We hope that after the reform of the computer course, that can give students some useful inspiration and help. The application of computer in the field has a more comprehensive understanding of computer applications. Learn some essential knowledge, and grasp the popular and practical application of the use of the software. To obtain self-choose to learn computer knowledge, to improve college students' quality of information technology, cultivate high-quality talents.

In the higher education information level of developed countries and regions, the creation of computer basic education in order to cultivate common early, to meet the needs of social development, many scholars have done a lot of related research. [3] According to the reform and exploration of the basic course of computer science, this paper emphasizes the combination of theory and practice, the "project teaching method", modular teaching and so on. [4] Later, the "project teaching method" hierarchical teaching has gradually become the mainstream of the university computer basic education reform, the majority of colleges and universities in our country have carried on the research and exploration to this teaching method, and has obtained certain achievement.

\section{The Main Problems and Causes of College Computer Basic Courses}

Basic Computer Education in Colleges and universities is faced with the "two non-starting point"-- not "zero starting point" and "the same starting point". With the popularity of our information technology literacy education to improve the national attention, conditional primary and middle schools have opened the course of information technology. At the same time, the freshmen's information literacy also rising, college computer basic education is no longer "from scratch". [5] But due to the economic development of our country is not balanced, the popularity of 
computer education in different degrees, backward areas due to the limitation of information technology courses stopped, which caused the freshmen there is a big difference in the aspect of information literacy.

Different Professional Requirements of the Computer Based on the Difference. Computer has been widely used in various industries, however, different professional computer skills requirements are also different and focus. The professional requirements of the basic computer teaching is getting higher and higher, and there is a big difference between the direct demand and dependence of the basic computer teaching. [6] Different professional teaching content is unified, not closely linked the university computer basic courses and students learn the professional.

Unified Teaching Syllabus and Teaching Requirements, cannot be "Teaching Students in Accordance with Their Aptitude". The teaching material is the main carrier and the important basis in the teaching process, also is the study important channel which the students obtain the knowledge. Therefore, the choice of teaching materials is particularly important. With the rapid development of computer technology, the hardware and software are updated very quickly, some of the content is too old and the form is single. Some textbooks are too higher. The theory is too strong, not suitable for students to learn.

The Practice Contents are Single, which do not Stimulate Students' Learning Potential and Innovation Consciousness. The practice of college computer foundation course is a very important link, which is to cultivate students' practical ability and the ability of comprehensive application of knowledge, and to cultivate students' creative ability and creative spirit. [7] Students now often in order to do the experiment, and not actively design the process. Some students don't even do the experiment, plagiarism test report, just doing things carelessly.

Examination evaluation. The examination is a kind of strict knowledge level appraisal method, also is the important link in the teaching process. The traditional college computer basic course performance evaluation method is mainly based on the closed volume written examination, the main content of the test is the theoretical knowledge, the less about the practical operation of the examination.

There are some disadvantages in the traditional college computer basic course examination which ignore the practice operation and emphasize the knowledge memory. Make the original practical, interesting, creative and strong operation become boring. The traditional examination mode has seriously restricted the students' initiative and practicality.

\section{The Practice of College Computer Basic Course Reform}

Diagnostic Testing. In the classification, The College has a total of 21 majors in grade 2016. Select 3 majors (business management, Chinese language and literature, art majors) to carry out thorough testing to understand the specific situation of the existing computer level students. Test the content and difficulty of the basic equivalent to the curriculum requirements. Including multiple-choice questions, filling in the blank questions and operating questions, subject knowledge include the operating system, the basic operation of office automation software, network and multimedia knowledge etc.. To understand the basic knowledge and skills of the students, and then to guide the different professional courses.

Teaching at Different Levels. It is difficult to meet the different needs of only one or several computer courses. [7] For this purpose, the college computer course system is set up according to 3 levels, namely, computer public courses, computer public or professional basic courses, as well as computer based professional courses.

On the basis of the creation of public courses, you can choose the following 14 categories of computer public courses. This is based on the three series of common features and requirements of the selected, with a certain representation. Each school can choose according to their own needs and the actual situation, but also the content of these courses can be properly combined to build a new class of small public computer courses. The following 14 courses, computer assembly and maintenance, and application of multimedia technology, computer network technology and 
application, Internet application, web site design and construction of foundation, dynamic web design, Internet technology, information retrieval and utilization of E-government, E-commerce applications, networking applications introduction, foundation and application of database, and program design and program design and application.

We classify of the above 3 professional students. The pilot program is mainly to weaken the classroom to explain, strengthen practice and independent learning. Maintain the basic requirements of network, database and multimedia. In the teaching week, use about 4 weeks to carry out computational thinking and programming algorithm teaching. Business management to understand the principles of computer and computer applications (multimedia, network, database) as the main content. It is suggested to set up the "University Computer Common Course ( 1 - to 6 modules) + database technology and application + computer elective courses related to major". Chinese language and literature majors master advanced applications and to strengthen the principle of computer office automation as the main content, creation of "university computer public course recommendations ( 1 - 4 modules) + Advanced Application of office automation (or other relevant professional elective courses in computer)".

In view of the history, philosophy and law teaching students set up courseware design, office automation, advanced applications, such as the basic professional courses. Art students (Art Design) to open the introduction of digital media art, multimedia technology applications, computer graphics and image basis, the basis of the design of art programming, such as the basic professional courses. Art students (vocal music) to set up a computer audio editing, multimedia music courseware design, computer sound synthesis, and other professional basic courses.

To Strengthen the Training of Computational Thinking Ability as the Core of Computer Basic Teaching Curriculum System and Teaching Content. The basic teaching of computer is an indispensable part of the cultivation of College Students' comprehensive quality and innovation ability, and it is also an important part of cultivating innovative talents. In the process of computer basic teaching, it embodies the modern educational idea of people oriented, imparting knowledge, cultivating ability, improving quality and harmonious development. [8]One of the important contents of to cultivate compound talents is to subtly enable them to develop a new way of thinking: to solve the problem, using the basic concept of computer science, system design and behavior understanding, namely the establishment of computational thinking. [9] From the perspective of cultivating students' thinking ability, the basic computer teaching not only raises the students' understanding of the computing environment, but also raises the problem solving method for the typical computing environment. In order to realize the reform of thinking teaching, the basic course of Computer Science in university should not only talk about knowledge, but also think of the knowledge. [10] In basic computer teaching, cultivating computational thinking of college students, so that students learn to use computational thinking to think and solve problems, it has important significance to cultivate outstanding talents, improve the level of teaching basic computer.

\section{Conclusion}

Through the practice of the teaching reform of computer basic course in University, We selected 200 students to conduct a questionnaire survey to investigate the satisfaction of the students on the teaching reform, as shown in figure 1 . Most of the students recognized the teaching reform, that the reform of the curriculum greatly increased the interest in learning, and teaching effect is significantly improved. 


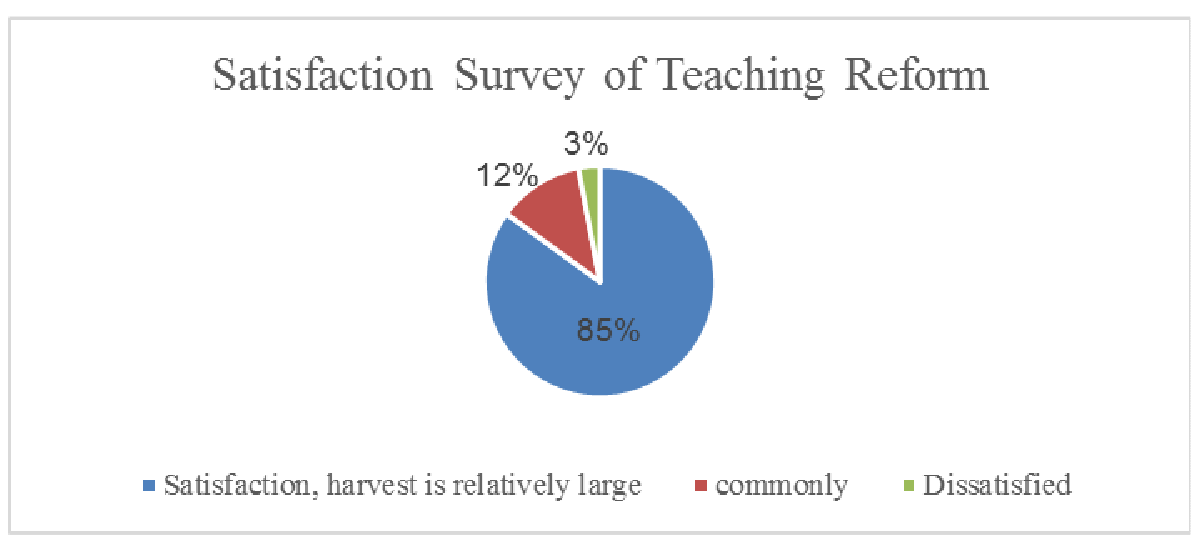

Figure 1. Student teaching reform satisfaction survey

Training of College Students' diversified mode of thinking, realize the talents training mode transformation, mode change to the application of compound talents training from academic talents; to adapt to the transformation of personnel training mode of university computer foundation curriculum must be reformed. It will promote the reform of the university computer teaching, the course construction and the construction of the three-dimensional teaching material according to the different professional types and application requirements. The teaching reform of computer basic course in university is a long process of practice.

\section{Acknowledgements}

Fund Project: The education of Jilin province "in 13th Five-Year" plan 2016 annual key project (Project No. ZD16071). Jilin Provincial Higher Education Association 2016 annual higher education research subject "based on SPOC" Access database technology and application "mixed teaching mode" (subject number: JGJX2016B27) results. 2016 Jilin higher education reform research project "based on MOOC+SPOC flipped classroom teaching mode" research results.

\section{References}

[1] Gu Yan, Song Wen, Liu Minhua, et al. Teaching reform and practice of College Computer Basic Course Based on ability training [J]. China University of Education, 2012, (08): 52-54.

[2] Li Zhiliang, Lin Hongkang, Luo Fang. The teaching reform of the basic computer course for application-oriented talents [J]. Journal of Ningde Normal University, 2014, (01): 71-73.

[3] Yang Jianlei. A new orientation for the reform of computer basic course in Universities in China based on Computational Thinking Theory [J]. Gansu Science and Technology, 2012, (15): 84-85+77.

[4] Zhou Liang. The reform and discussion of computer basic courses for non computer majors in Colleges and universities [J]. Computer Science and Technology, 2010, (20): 5563-5564.

[5] Zhou Xingguo, Dai Juan. Study on the reform of basic computer courses in University [J]. New West, 2010, (09): 220+187.

[6] Li Fangsong. My opinion on the teaching reform of computer basic courses [J]. Computer Education, 2015, (06): 44-46+55.

[7] Sheng Minghui. University Computer Foundation Course inquiry teaching model of [D]. Northeast Normal University, 2011.

[8] Wu Ning, Cui Wei. Research on the reform of the teaching content of College Computer Basic Courses Based on the cultivation of Computational Thinking Ability [J]. Computer Education, 2012, (07): 107-110. 
[9] Leslie Cheung. A new approach to the reform of University Computer Foundation Course Based on flipped classroom [J]. University Education, 2013, (13): 135-137+154.

[10] Ma Ma. Exploration of computer basic curriculum reform based on Computational Thinking [J]. Forum on Industry and Technology, 2015, (24): 183+186. 